\title{
Tyrosine Phosphorylation of the Inactivating Peptide of the Shaker B Potassium Channel: A Structural-Functional Correlate ${ }^{\dagger}$
}

\author{
J. A. Encinar, ${ }^{\ddagger}$ A. M. Fernández,${ }^{\ddagger}$ M. L. Molina, ${ }^{\ddagger}$ A. Molina, ${ }^{\S}$ J. A. Poveda, ${ }^{\ddagger}$ J. P. Albar, ${ }^{\Perp}$ J. López-Barneo,${ }^{\perp}$ \\ F. Gavilanes, ${ }^{\#}$ A. V. Ferrer-Montiel, ${ }^{\ddagger}$ and J. M. González-Ros* ${ }^{*}$
}

Centro de Biologia Molecular y Celular, Universidad Miguel Hernández, 03202 Elche (Alicante), Spain, Neuropharma S. A., Avda de la Industria 52, Tres Cantos, 28760 Madrid, Spain, Departamento de Inmunología y Oncología, Centro Nacional de Biotecnología, CSIC, Cantoblanco, 28049 Madrid, Spain, Laboratorio de Investigaciones Biomédicas, Hospital Universitario Virgen del Rocio, Avda Manuel Siurot s/n, E-41013 Sevilla, Spain, and Departamento de Bioquímica, Facultad de Ciencias Químicas, Universidad Complutense, 28040 Madrid, Spain

Received March 7, 2002; Revised Manuscript Received July 11, 2002

\begin{abstract}
A synthetic peptide patterned after the sequence of the inactivating "ball" domain of the Shaker $\mathrm{B} \mathrm{K}^{+}$channel restores fast (N-type) inactivation in mutant deletion channels lacking their constitutive ball domains, as well as in $\mathrm{K}^{+}$channels that do not normally inactivate. We now report on the effect of phosphorylation at a single tyrosine in position 8 of the inactivating peptide both on its ability to restore fast channel inactivation in deletion mutant channels and on the conformation adopted by the phosphorylated peptide when challenged by anionic lipid vesicles, a model target mimicking features of the inactivation site in the channel protein. We find that the inactivating peptide phosphorylated at Y8 behaves functionally as well as structurally as the noninactivating mutant carrying the mutation L7E. Moreover, it is observed that the inactivating peptide can be phosphorylated by the Src tyrosine kinase either as a free peptide in solution or when forming part of the membrane-bound protein channel as the constitutive inactivating domain. These findings suggest that tyrosine phosphorylation-dephosphorylation of this inactivating ball domain could be of physiological relevance to rapidly interconvert fast-inactivating channels into delayed rectifiers and vice versa.
\end{abstract}

Fast (N-type) inactivation of voltage-activated potassium $\left(\mathrm{K}_{\mathrm{v}}\right)^{1}$ channels occurs by a "ball and chain" mechanism in which a flexible N-terminal domain (the "ball") of the channel protein acts as an open channel blocker and physically occludes the cytoplasmic channel mouth $(1,2)$. In the Shaker B $\mathrm{K}_{\mathrm{v}}$ channel (3) the inactivating "ball" domain corresponds to the first 20 amino acids in the $\mathrm{N}$-terminal region of each of the four Shaker B channel subunits $\left(\mathrm{H}_{2} \mathrm{~N}\right.$ MAAVAGLYGLGEDRQHRKKQ). These Shaker B ball domains behave independently $(4,5)$, each causing channel inactivation in a mutually exclusive manner.

Following the identification of the ball domain in the Shaker B K ${ }^{+}$channel, it was found that intracellular addition

\footnotetext{
$\dagger$ Partly supported by grants from the Spanish DGESIC, CICYT, Fundación La Caixa, Fundación Juan March (Ayuda a la Investigación 2000), and the European Comission.

* To whom correspondence should be addressed. Phone: + 3496 6658757. Fax: + 3496 6658758. E-mail: gonzalez.ros@umh.es.

†niversidad Miguel Hernández.

$\S$ Neuropharma S. A.

"Centro Nacional de Biotecnología, CSIC

${ }^{\perp}$ Hospital Universitario Virgen del Rocio.

\# Universidad Complutense.

${ }^{1}$ Abbreviations: $\mathrm{K}_{\mathrm{v}}$, voltage-activated potassium channels; Shaker $\mathrm{B} \mathrm{K}{ }^{+}$channel, one of the spliced variants of the voltage-dependent, fast-inactivating $\mathrm{K}^{+}$channels coded in the Shaker locus of Drosophila; $\mathrm{ShB}$ peptide, inactivating peptide of the Shaker B K ${ }^{+}$channel; ShB 8-P, ShB peptide phosphorylated at Y8; PG, phosphatidylglycerol prepared from egg yolk PC; PA, phosphatidic acid prepared from egg yolk PC; DMPG, 1,2-dimyristoyl-sn-glycero-3-phosphatidylglycerol; DMPA, 1,2-dimyristoyl-sn-glycero-3-phosphate; FTIR, Fourier transform infrared spectroscopy; DSC, differential scanning calorimetry.
}

of a synthetic peptide (ShB inactivating peptide) patterned after the "ball" sequence fully restores fast inactivation in mutant Shaker B channels that do not inactivate because of deletions in their $\mathrm{N}$-terminal region, suggesting that the synthetic peptide contains all of the necessary molecular determinants to recognize the channel protein and induce inactivation (O). Furthermore, the ShB inactivating peptide serves also as an inactivating ball for a variety of other $\mathrm{K}_{\mathrm{v}}$ channels $(6-8)$, high- and intermediate-conductance, $\mathrm{Ca}^{2+}$ activated $\mathrm{K}^{+}$channels $(9-11)$, or cyclic nucleotide-gated channels (12), some of which do not normally inactivate. Similarly, other putative ball peptides were identified in several Shaker splicing variants, as well as in mammalian $\mathrm{K}_{\mathrm{v}}$ channels, which were also efficient blockers of the Shaker $\mathrm{B} \mathrm{K}^{+}$channel despite the lack of sequence homology (13). From the above "crossed" inactivation phenomena, it was concluded that the molecular recognition events leading to the formation of the inactivating peptide/channel complex and, thus, to channel inactivation have a rather unconstrained basis in terms of primary structure and that there must be two relevant domains, complementary to those in the ball peptides, configuring the receptor site for the inactivating peptide in the channel protein: (i) a hydrophobic pocket, which becomes accessible only upon channel opening, separated from the cytoplasm by (ii) a region with a negative surface potential (14-16). Such conclusions received support from the crystallographic structure of the prokaryotic KcsA channel $(17,18)$ in which the central cavity and inner channel 
pore are lined by hydrophobic amino acids, while the surrounding cytoplasmic $\mathrm{T} 1-\mathrm{S} 1$ linker domains contain many acidic amino acids to favor electrostatic interaction with the positively charged amino acids found near the C-terminus in most ball peptides.

Attempting to gain insight into the molecular events in which the inactivating peptide might be involved during channel inactivation, anionic phospholipid vesicles were used as a model target to partly mimic the corresponding domains in the channel's inactivation site, as it also contained a region with a negative surface potential (the negatively charged vesicle surface) and a hydrophobic domain (the lipid bilayer). From these studies it was concluded that the ShB peptide in a monomeric form (i) binds to the anionic surface with high affinity, (ii) readily adopts a strongly hydrogen-bonded, intramolecular $\beta$-structure (a $\beta$-hairpin), and (iii) becomes partly inserted into the hydrophobic bilayer (19-21). Modeling a hypothetical "channel-bound" conformation for the ShB peptide from these results predicted that introduction of charged groups near the bend at G6 of the hydrophobic $\beta$-hairpin should prevent it from adopting its characteristic $\beta$-structure and from inserting into hydrophobic environments, thus resulting in noninactivating peptide mutants. Indeed, this is the case for noninactivating Shaker mutants such as the L7E or L7R (3). We are now reporting on the effects of a physiologically relevant covalent modification that would introduce a negatively charged group near the tip of the presumed $\beta$-hairpin: the phosphorylation of the single tyrosine residue in the $\mathrm{ShB}$ peptide sequence. As predicted by the model, it is observed that the phosphorylated peptide behaves both functionally and structurally as a noninactivating mutant. Interestingly, this was also the case in the phosphorylation of serine residues of the inactivating peptide of the mammalian $\mathrm{K}_{\mathrm{v}} 3.4$ channel (Raw 3) (22-24). Moreover, the Raw 3 peptide, having a primary sequence completely different from that of the ShB peptide, also adopted $\beta$-structure when challenged by anionic lipid vesicles (25) and lost structural stability upon phosphorylation (24).

\section{MATERIALS AND METHODS}

The wild-type ShB peptide (MAAVAGLYGLGEDRQHRKKQ) (3) was synthesized as a C-terminal amide on an automatic multiple synthesizer (AMS 422, Abimed) using a solid-phase procedure and standard Fmoc chemistry (19). For the synthesis of ShB peptide phosphorylated at Y8 (ShB 8-P), the phosphotyrosine Fmoc derivative (Novabiochem) was used. All peptides were purified by reverse-phase HPLC to better than $95 \%$ purity, and their composition and molecular mass were confirmed by amino acid analysis and mass spectrometry, respectively (19). Residual trifluoroacetic acid used both in the peptide synthesis and in the HPLC mobile phase [the trifluoroacetate ion has a strong infrared absorbance at $1673 \mathrm{~cm}^{-1}$, which interferes with the characterization of the amide I band (26)] was removed by submitting the peptides to several lyophilization-solubilization cycles in $10 \mathrm{mM} \mathrm{HCl}$ (27).

Purified ShB peptide in solution was also enzymatically phosphorylated in the presence of the tyrosine kinase Src (Upstate Biotechnology, Inc.) and $\left[\gamma^{-32} \mathrm{P}\right] \mathrm{ATP}$, as previously reported (28). Dephosphorylation of $\mathrm{ShB} 8-{ }^{32} \mathrm{P}$ was carried out using agarose-conjugated PTP-1B phosphatase (Upstate
Biotechnology, Inc.), as reported (28). The extent of tyrosine phosphorylation-dephosphorylation was assessed by SDSPAGE and autoradiography.

Shaker B $\Delta 6-46 \mathrm{~K}^{+}$channel cDNA $(3,29)$ was transiently expressed in $\mathrm{CHO}$ cells using the p513 vector (Stratagene) (30). Cell culture and electroporation conditions were as described previously (31). Ionic currents were recorded 24$48 \mathrm{~h}$ after transfection, using the whole cell configuration of the patch-clamp technique (32), as described (31). Experiments were done in cells expressing between 0.8 and $1.2 \mathrm{nAmp}$ of peak current amplitudes at $+20 \mathrm{mV}$.

cDNA coding for Drosophila Shaker B and Shaker B $\Delta 6$ $46 \mathrm{~K}^{+}$channels was transcribed "in vitro" and the resulting RNA injected into Xenopus oocytes ( $\sim 10 \mathrm{ng}$ per oocyte) (33). Ionic currents were recorded 2-4 days after injection using a two-electrode voltage clamp technique (34) to check for the correct expression of the constructs in the oocyte membrane. Twenty oocytes per sample were collected, lysed, and homogenized as described (35). Crude oocyte membrane fractions were phosphorylated with Src kinase (Upstate Biotechnology, Inc.) for $3 \mathrm{~h}$ at $30^{\circ} \mathrm{C}$. The phosphorylation reaction (final volume of $300 \mu \mathrm{L}$ ) was carried out in $20 \mathrm{mM}$ Hepes buffer, $\mathrm{pH} 7.4,20 \mathrm{mM} \mathrm{MgCl}_{2}$, and $0.1 \mathrm{mM}$ EGTA in the presence of Src kinase ( 0.05 unit/ $\mu \mathrm{L}$ of membrane), $0.2 \mathrm{mM}$ dithiothreitol, and $0.2 \mathrm{mM}$ ATP. The reactions were stopped by addition of $25 \mathrm{mM}$ EDTA. Proteins binding to the agarose-conjugated protein $\mathrm{G}$ matrix in the absence of antibodies (nonspecific binding) were removed by centrifugation after $1 \mathrm{~h}$ incubation with the agarose beads. Then supernatants were immunoprecipitated with anti-phosphotyrosine monoclonal antibody (clone 4G10, Upstate Biotechnology, Inc.) $(20 \mu \mathrm{g} / \mathrm{mL})$, and immunocomplexes were captured with agarose-conjugated protein $\mathrm{G}$ (Pierce) as described (28). The immunoprecipitates were heated $30 \mathrm{~min}$ at $50{ }^{\circ} \mathrm{C}$ in $80 \mu \mathrm{L}$ of SDS-PAGE loading buffer, separated in a PAGE-SDS gel (9\%), and transferred to a nitrocellulose membrane. The nitrocellulose was blocked with $3 \%$ bovine serum albumin, probed with $4 \mu \mathrm{g} / \mu \mathrm{L}$ anti-Shaker $\alpha$-ShHX1 polyclonal antibody (a generous gift of Dr. F. Tejedor, CSIC, University Miguel Hernandez) (36), and detected with an alkaline phosphatase-conjugated anti-IgG antibody (Sigma). Bands in the immunoblots were visualized using the alkaline phosphatase conjugate substrate kit system (Bio-Rad Laboratories).

The phospholipids phosphatidylglycerol (PG) and phosphatidic acid (PA) (Avanti Polar Lipids) used in the infrared spectroscopy studies derive from egg yolk PC and, therefore, have the same fatty acid composition. For infrared amide I band recordings, lyophilized aliquots of the synthetic peptides and the desired lipids were separately hydrated in a bathtype sonicator in $25 \mu \mathrm{L}$ of $\mathrm{D}_{2} \mathrm{O}$ buffers (see figure legends for details on the composition of the buffers) to avoid the interference of $\mathrm{H}_{2} \mathrm{O}$ infrared absorbance $\left(1645 \mathrm{~cm}^{-1} ; 37\right)$. The resulting solutions were mixed by placing them together into a liquid demountable cell (Harrick, Ossining, NY) equipped with $\mathrm{CaF}_{2}$ windows and $50 \mu \mathrm{m}$ thick Mylar spacers and maintained at room temperature for approximately 30 min to ensure that the isotopic $\mathrm{H}-\mathrm{D}$ amide proton exchange reached equilibrium, as judged by a constant minimal absorbance at the residual amide II band in the peptide's infrared spectra. The peptide concentrations in the final mixtures ranged from 1.1 to $4.5 \mathrm{mM}$, while the phospholipids 
were used at approximately $32.8 \mathrm{mM}$, thus resulting in phospholipid to peptide molar ratios ranging from 7.3 to 29.8 . Infrared spectra were taken in a Nicolet 520 instrument equipped with a DTGS detector, as previously described (38), using 200 spectral scans to define the amide I band. No resolution-enhancement techniques (Fourier derivation or deconvolution) were applied to the spectral data.

For differential scanning calorimetry (DSC) large multilamellar vesicles made from synthetic dimyristoylphosphatidic acid (DMPA) and dimyristoylphosphatidylglycerol (DMPG) (Avanti Polar Lipids) were used. Dried lipid films obtained from chloroform solutions were suspended in the required buffer (see figure legends for details) to give a final concentration of $2 \mathrm{mM}$ in terms of lipid phosphorus. The suspended lipids were kept for 90 min above their phase transition temperatures and vortexed. The resulting liposomes were stored overnight, at $4{ }^{\circ} \mathrm{C}$, to ensure a complete hydration of the sample prior to the DSC experiments. Thermograms were recorded on a high-resolution Microcal MC-2 differential scanning microcalorimeter, equipped with the DA-2 digital interface and data acquisition utility for automatic data collection, as described earlier (39). The lipid dispersions containing added ShB or ShB 8-P peptides at different molar ratios and the corresponding buffer in the reference cell were thermally equilibrated in the microcalorimeter, at $\sim 10{ }^{\circ} \mathrm{C}$ during $45 \mathrm{~min}$, before heat was applied. Differences in the heat capacity between the sample and the reference cell were obtained by raising the temperature at a constant rate of 45 ${ }^{\circ} \mathrm{C} / \mathrm{h}$. Transition temperatures and enthalpies were calculated by fitting the observed transitions to a single van't Hoff component. Reported transition temperatures correspond to those at which there is a maximum differential heat capacity, as observed in the thermograms.

\section{RESULTS}

Functional Effects of Chemical Phosphorylation of the ShB Peptide at Y8. The ability of the synthetic ShB peptide and its chemically phosphorylated derivative at Y8 (ShB 8-P) to restore $\mathrm{N}$-type $\mathrm{K}^{+}$channel inactivation was tested by studying their effects in the Shaker $\mathrm{B} \Delta 6-46 \mathrm{~K}^{+}$channel mutant that lacks the constitutive inactivating peptide moiety present in the wild-type Shaker B $\mathrm{K}^{+}$channel $(3,29)$. As illustrated in Figure 1, macroscopic currents elicited in response to depolarizing pulses in transfected $\mathrm{CHO}$ cells expressing Shaker B $\Delta 6-46$ channels inactivate very slowly, with an inactivation time constant of $1300 \pm 160$ ms (mean $\pm \mathrm{SD}, n=6$ ), characteristic of the C-type, slow inactivation process exhibited also by this channel (29). Addition of native, unphosphorylated ShB peptide restores N-type rapid channel inactivation, with an inactivation time constant of $215 \pm 48 \mathrm{~ms}(n=6)$. In contrast, addition of the chemically phosphorylated ShB 8-P peptide produces only a slight increase in the inactivation constant to $766 \pm 87 \mathrm{~ms}(n=$ 6). These results show that phosphorylation of the ShB peptide causes a significant loss in its ability to induce rapid channel inactivation, similar to that observed for certain noninactivating mutants of the ShB peptide, such as the $\mathrm{ShB}$ L7E peptide (6).

In addition to the above, analysis of the kinetics of channel activation indicates that neither peptide unphosphorylated or tyrosine-phosphorylated alters the voltage-dependent activation rates of the Shaker B $\Delta 6-46$ channel (Table 1).

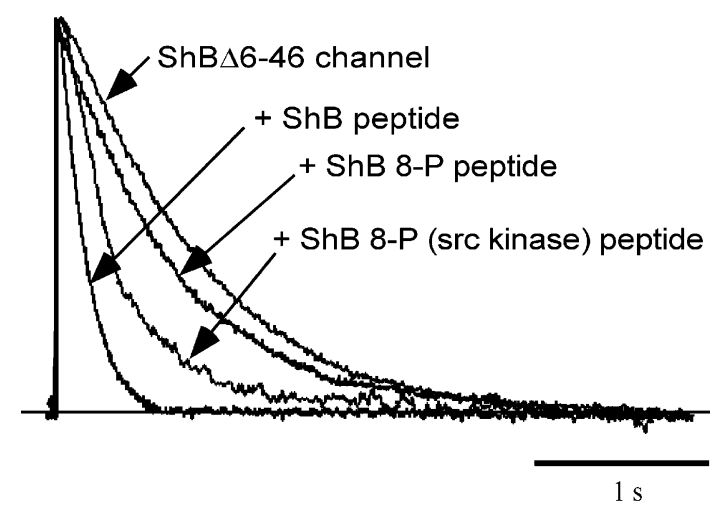

FIGURE 1: Restoration of fast (N-type) inactivation in the deletion mutant Shaker B $\Delta 6-46 \mathrm{~K}^{+}$channel. Slow (C-type) inactivation of the Shaker B $\Delta 6-46$ channel in the absence of inactivating peptides is shown as a control. The figure shows the effects of the native ShB peptide, chemically phosphorylated ShB 8-P peptide, and enzymatically (Src kinase) phosphorylated ShB 8-P peptide on restoring fast inactivation in the Shaker B $\Delta 6-46$ channel. The whole cell configuration of the patch-clamp technique was used in these studies. The external bathing solution ( $\mathrm{pH} 7.4$ ) contained (in $\mathrm{mM}$ ) $140 \mathrm{NaCl}, 2.7 \mathrm{KCl}, 2.5 \mathrm{CaCl}_{2}, 4 \mathrm{MgCl}_{2}$, and 10 Hepes. The pipet solution ( $\mathrm{pH}$ 7.2) contained (in $\mathrm{mM}$ ) $80 \mathrm{KCl}, 30$ potassium glutamate, $20 \mathrm{KF}, 4 \mathrm{MgCl}_{2}$, 4 ATP, 10 EGTA, and 10 Hepes. In all cases, the peptides were dissolved in the pipet solution at a concentration of $500 \mu \mathrm{M}$.

In Vitro and "in Situ" Phosphorylation of the ShB Peptide by the Tyrosine Kinase Src. Incubation of the purified ShB inactivating peptide in the presence of Src, a tyrosine kinase particularly abundant in neurons $(40,41)$ and $\left[\gamma_{-}{ }^{32} \mathrm{P}\right] \mathrm{ATP}$, results in the efficient incorporation of radioactive ${ }^{32} \mathrm{P}$ on a electrophoretic band migrating as the unlabeled peptide does (Figure 2). This enzymatic phosphorylation reaction was also reversible, as demonstrated by dephosphorylation in the presence of the PTB-1B phosphatase (not shown). The extent of tyrosine phosphorylation was time dependent, with an apparent half-maximum at $\sim 15$ min of incubation (Figure 2 ). At saturation, the stoichiometry of the phosphorylation reaction was approximately $0.7 \mathrm{~mol}$ of ${ }^{32} \mathrm{P} / \mathrm{mol}$ of peptide. Higher stoichiometries were not obtained probably due to end-product inhibition of the enzyme (42). Such stoichiometry seemed consistent with the observed effects of enzymatically phosphorylated $\mathrm{ShB}$ on the inactivation of Shaker B $\Delta 6-46$ channels (Figure 1), which proceeded halfway between that seen for the native, unphosphorylated ShB peptide and the chemically phosphorylated one, with inactivation time constants of $634 \pm 81 \mathrm{~ms}$ (Table 1). Altogether, these results demonstrate that the $\mathrm{ShB}$ peptide in solution is an adequate substrate for in vitro enzymatic phosphorylation at the single $\mathrm{Y} 8$ residue.

To determine whether the ShB peptide could also be phosphorylated by Src in situ, i.e., when the peptide forms part of the membrane-bound channel protein as a constitutive inactivation ball domain, we use heterologous expression of Shaker B and Shaker B $\Delta 6-46 \mathrm{~K}^{+}$channels in Xenopus oocytes. Membrane fractions from oocytes expressing either the wild-type channel or the deletion channel mutant, along with membrane fractions from uninjected oocytes, were submitted to phosphorylation by Src in the presence of ATP and the phosphorylated protein products analyzed by immunoblotting with anti-Shaker polyclonal antibodies after inmunoprecipitation with anti-phosphotyrosine $\mathrm{mAb}$ (Figure 3 ). The immunoblot from oocytes expressing wild-type 
Table 1: Effect of the ShB, Chemically Phosphorylated ShB 8-P, and Src-Phosphorylated ShB 8-P Peptides on the Rates of Activation and Inactivation of Shaker B $\Delta 6-46$ Currents $^{a}$

\begin{tabular}{|c|c|c|c|c|}
\hline \multirow[b]{2}{*}{ peptide } & \multicolumn{3}{|c|}{$t_{1 / 2}$ activation $(\mathrm{ms})^{b}$} & \multirow{2}{*}{$\frac{\tau \text { inactivation }(\mathrm{ms})^{c}}{+20 \mathrm{mV}}$} \\
\hline & $-20 \mathrm{mV}$ & $0 \mathrm{mV}$ & $+20 \mathrm{mV}$ & \\
\hline control (no peptide) & $5.63 \pm 1.12(7)$ & $3.28 \pm 0.43(8)$ & $2.32 \pm 0.21(8)$ & $1300 \pm 160(6)$ \\
\hline ShB & $4.91 \pm 0.95$ & $3.17 \pm 0.39(7)$ & $2.22 \pm 0.23(6)$ & $215 \pm 48(6)$ \\
\hline ShB 8-P & $5.87 \pm 1.03(5)$ & $3.39 \pm 0.47(5)$ & $2.38 \pm 0.36(5)$ & $766 \pm 87(6)$ \\
\hline ShB 8-P (Src kinase) & $5.65 \pm 0.89(4)$ & $3.35 \pm 0.32(4)$ & $2.17 \pm 0.29(4)$ & $634 \pm 81(5)$ \\
\hline
\end{tabular}

${ }^{a}$ Data represent the mean \pm standard deviation of the number of experiments indicated in parentheses. Time is given in milliseconds. The holding potential was $-80 \mathrm{mV} .{ }^{b}$ Activation kinetics are compared by measuring the time needed to reach $50 \%$ of the maximal current amplitude $\left(t_{1 / 2}\right)$ at $-20,0$, and $+20 \mathrm{mV} .{ }^{c}$ Inactivation time course is studied by measuring the time needed to remain $1 / \mathrm{e}$ of the maximal current amplitude ( $\tau$ inactivation) at $+20 \mathrm{mV}$. $\tau$ inactivation was estimated from single-exponential fits to the current traces.

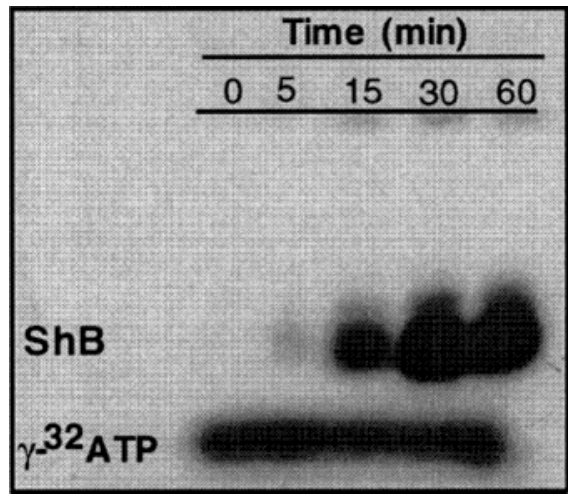

FIGURE 2: Autoradiography of an SDS-PAGE gel illustrating the kinetics of phosphorylation of the ShB peptide in solution by Src kinase and $\left[\gamma_{-}{ }^{32} \mathrm{P}\right] \mathrm{ATP}$ at different times of incubation $(0,5,15$, 30 , and $60 \mathrm{~min}$ ). The experimental conditions for the phosphorylation reaction were as reported previously (28). Reactions proceeded at $30{ }^{\circ} \mathrm{C}$ for the indicated times and were terminated by addition of SDS-PAGE sample buffer. Phosphorylated samples subjected to SDS-PAGE on $8 \%$ gels were stained with Coomassie Blue R-250, destained, dried, and exposed to Kodak X-Omat AR $\mathrm{X}$-ray film.

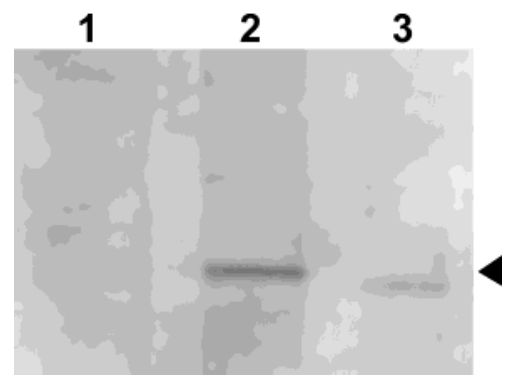

FIGURE 3: Western immunoblot to illustrate Src phosphorylation of wild-type Shaker B and Shaker B $\Delta 6-46$ channels expressed in Xenopus oocytes (see Materials and Methods). Lane 1 corresponds to uninjected oocytes shown as a control, while lanes 2 and 3 correspond to oocytes expressing the wild-type, entire Shaker B $\mathrm{K}^{+}$channel and the deletion mutant Shaker B $\Delta 6-46$ channel, respectively. A $60 \mathrm{kDa}$ electrophoretic band reactive to anti-Shaker $\alpha$-ShHX1 polyclonal antibody in lane 2 is indicated by an arrowhead.

Shaker B K ${ }^{+}$channels shows an anti-Shaker reactive protein band of approximately $60 \mathrm{kDa}$ in the anti-phosphotyrosine $\mathrm{mAb}$ inmunoprecipitate. Such a band seems not to be present in the uninjected oocytes and has only a fainter counterpart with a slightly higher electrophoretic mobility in the oocytes expressing the deletion Shaker B $\Delta 6-46$ channels (the expected difference in molecular mass between the wild-type and the deletion channel is only about $4500 \mathrm{Da}$ ). Moreover, the size of such a protein corresponds roughly to one of the

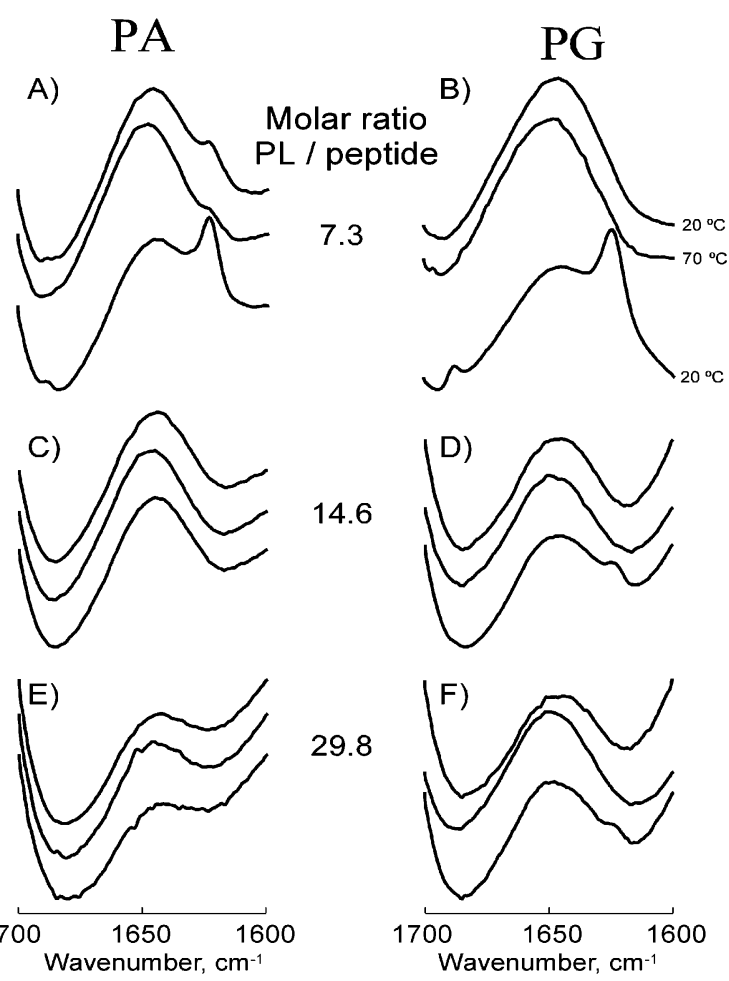

FIGURE 4: Amide I band region of the original spectra of the ShB peptide in the presence of PA (A, C, E) and PG (B, D, F) lipid vesicles. The samples were suspended in a $\mathrm{D}_{2} \mathrm{O}$ media prepared from $10 \mathrm{mM}$ Hepes buffer, $\mathrm{pD} 7.4$, containing $130 \mathrm{mM} \mathrm{KCl}$ and $20 \mathrm{mM} \mathrm{NaCl}(\mathrm{pD}=\mathrm{pH}+0.4)$. The triplets of traces shown in all panels correspond to spectra of samples taken at $20^{\circ} \mathrm{C}$ (lower traces in each triplet), spectra taken in samples heated at $70{ }^{\circ} \mathrm{C}$ (middle traces, heat-denatured samples), and spectra of the heated samples after being recooled to $20{ }^{\circ} \mathrm{C}$ (upper traces, renatured samples). The phospholipid/peptide molar ratios were $7.3(\mathrm{~A}, \mathrm{~B}), 14.6(\mathrm{C}$, D), and 29.8 (E, F).

major glycosylated forms of Shaker B $\mathrm{K}^{+}$channels when expressed in oocytes (43). These observations, along with the fact that there are no tyrosines other than Y8 in the deleted 6-46 amino acid sequence (44), suggest that, indeed, Y8 may also be a substrate for Src in the intact, membranebound Shaker B $\mathrm{K}^{+}$channel.

Challenging the Phosphorylated ShB 8-P Peptide by Anionic Phospholipid Vesicles, a Model Target Mimicking Features of the Inactivation "Gate" of $\mathrm{K}^{+}$Channels. Figure 4 shows that, in the presence of anionic lipid vesicles made of either PA (Figure 4A) or PG (Figure 4B), the adoption of $\beta$-structure by the phosphorylated ShB 8-P peptide is concentration dependent, as revealed by the appearance of the $1623 \mathrm{~cm}^{-1}$ component in the infrared amide I band only 


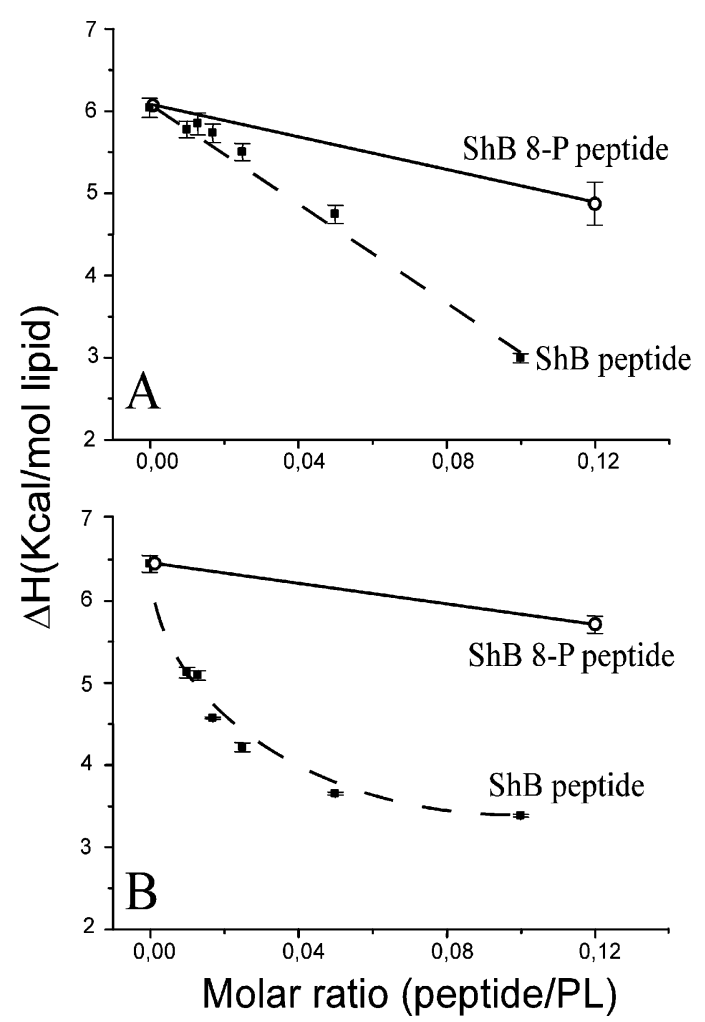

FIGURE 5: Changes in the gel to liquid crystal phase transition enthalpies of DMPG (panel A) and DMPA (panel B) large multilamellar vesicles in the presence of increasing concentrations of either native $\mathrm{ShB}(\boldsymbol{\square})$ or phosphorylated $\mathrm{ShB}$ 8-P (O) peptides, as determined by differential scanning calorimetry (see Materials and Methods) of the indicated phospholipid/peptide mixtures in 10 $\mathrm{mM}$ Hepes, $\mathrm{pH} 7.0$, and $100 \mathrm{mM} \mathrm{NaCl}$. Error bars represent standard deviations. The presence of the peptides had no effects on the phase transition temperatures of either DMPG or DMPA.

at high peptide to anionic phospholipid ratios (Figure 4A,B). Furthermore, the adopted $\beta$-structure, which likely results from intermolecular hydrogen bonding, is not stable with increasing temperature (Figure 4) and does not recover upon recooling of the previously heated sample (upper traces in all panels of Figure 4). These observations are in contrast with those reported previously for the native, unphosphorylated ShB peptide in which the adopted intramolecular $\beta$-structure, a $\beta$-hairpin, does not depend on the concentration of the peptide, is highly stable with temperature, and recovers almost fully upon recooling (20). Moreover, the alluded behavior for the phosphorylated ShB 8-P peptide resembles closely that reported previously for the mutant, noninactivating ShB L7E peptide (20).

In addition to folding as a $\beta$-hairpin, the ability to insert into the hydrophobic bilayer is probably what distinguishes best between inactivating and noninactivating peptides in their interaction with the anionic vesicle model targets (20). Figure 5 shows DSC studies at neutral $\mathrm{pH}$, in which the different peptides are confronted to vesicles made of synthetic dimyristoylphosphatidylglycerol (DMPG, panel A) and dimyristoylphosphatidic acid (DMPA, panel B), which have convenient phase transition temperatures at 23.3 and 49.6 ${ }^{\circ} \mathrm{C}$, respectively. As reported previously (20), the presence of the native unphosphorylated ShB peptide causes a large, concentration-dependent decrease in the transition enthalpy, which is slightly more pronounced in DMPG than in DMPA vesicles, without modifying the phase transition temperature.
This is due to peptide insertion into the bilayer (21) in which the interaction of the peptide with the phospholipid acyl chains prevents part of the phospholipid molecules from undergoing the phase transition characteristic of the "pure" phospholipid species and, thus, decreases the phase transition enthalpy in a peptide concentration-dependent manner (45). On the contrary, the phosphorylated ShB 8-P peptide, both in DMPA and DMPG vesicles, does not significantly affect either the phase transition enthalpy or the phase transition temperature, even at high peptide concentration. This behavior of the phosphorylated peptide should be interpreted as being unable to insert into the hydrophobic bilayer and resembles very closely that exhibited by the mutant, noninactivating ShB L7E peptide (21).

\section{DISCUSSION}

Potassium channels display the largest molecular diversity of all ion channel families. They are widely distributed in different cell types of practically all living organisms, where they contribute to the control of potassium flow, cell volume, release of hormones and transmitters, resting potential, excitability, and behavior (46). In addition to being controlled at the level of protein synthesis and/or transport to the membrane, the different potassium channels may be regulated by a variety of "short-term" mechanisms including changes in the membrane potential or presence of regulatory $\beta$-subunits, transmitters, and hormones (47). More recently, it has been found that potassium channels may also be regulated by posttranslational covalent modifications, such as phosphorylation on specific serine and threonine residues as well as on the less frecuently observed, tyrosine residues $(48,49)$. Channel phosphorylation results in alteration of either (i) the levels of channel protein reaching the plasma membrane, (ii) the potassium current amplitude, or (iii) the kinetics of inactivation. In regard to the latter, the modulation of the inactivation kinetics in a voltage-dependent potassium channel by direct phosphorylation at the inactivating ball domain has been demonstrated to date only in a cloned human potassium channel, the $\mathrm{K}_{\mathrm{v}} 3.4$ channel, a member of the Shaw subfamily of potassium channel genes (22). When expressed in oocytes and in the presence of activators of protein kinase $\mathrm{C}$, the $\mathrm{K}_{\mathrm{v}} 3.4$ channel goes from exhibiting rapidly inactivating A-type currents to typical delayed rectifier currents as a consequence of phosphorylation of at least two serine residues (S15 and S21) near the N-terminus of the channel protein (22). Moreover, synthetic unphosphorylated Raw 3 peptide (the inactivating constitutive ball domain of the $\mathrm{K}_{\mathrm{v}} 3.4$ channel) restores fast inactivation in the noninactivating $\mathrm{K}_{\mathrm{v}} 1.1$ channel, but phosphorylation of the peptide at either one or several of the existing serine residues leads to reduction or complete removal of its ability to induce fast inactivation (24). Therefore, it seems that phosphorylation causes steric hindrances in the inactivation peptide that makes it unable to recognize the inactivation site on the channel and, thus, converts it to a noninactivating species.

At variance with the inactivating peptide of the $\mathrm{K}_{\mathrm{v}} 3.4$ channel, the inactivating ShB peptide does not have any serine or threonine residues as potential phosphorylation sites. However, on the basis of a structural model postulated to account for the conformation of the peptide when bound to the inactivation site on the channel protein (21), the hypothetical phosphorylation of the single tyrosine residue 
at position 8 is predicted to prevent the peptide from folding as an intramolecular $\beta$-hairpin and from inserting into hydrophobic pockets. Thus, modification of this residue should result in the loss of the peptide ability to rapidly inactivate the channel activity. Indeed, ShB 8-P prepared in vitro either chemically or enzymatically completely fulfilled such expectations. For the functional point of view, the phosphorylated peptide cannot induce rapid inactivation in the Shaker B $\Delta 6-46$ deletion channel, while structurally, it can neither adopt an intramolecular $\beta$-hairpin structure when confronted to the anionic lipid vesicles as model targets nor insert into the hydrophobic environment provided by the lipid bilayer of such vesicles. Therefore, it seems plausible that the steric effects of phosphorylation referred above for the Raw 3 peptide, could be related in the ShB peptide to preventing its adequate folding and subsequent insertion into hydrophobic pockets. As a matter of fact, the behavior of the ShB 8-P is barely distinguishable from that of noninactivating peptide mutants such as the $\operatorname{ShB} \operatorname{L7E}(3,20,21$, $31)$.

The above observations provide a nice example of a structure-function relationship in a synthetic peptide that seemingly contained all of the necessary molecular determinants to recognize its target and carry out its function. Also, in our interpretation, these observations provide additional support to our previous proposal to explain the interaction of the inactivating peptide as a $\beta$-hairpin with the channel protein (21). Indeed, every experimental condition found to interfere with the ability of the ShB peptide to adopt the $\beta$-hairpin structure and to insert into the bilayer provided by the anionic vesicles, including Y8 phosphorylation, correlates with a loss in its ability to induce channel inactivation. Furthermore, in light of the known crystal structure of the KcsA channel, it seems feasible that the hydrophobically lined channel inner pore in its open conformation could accommodate the inactivation peptide as an intramolecular $\beta$-hairpin. In fact, the width of such a $\beta$-hairpin would not exceed the dimensions of tetrabutylammonium or tetrabutylantimony, quaternary amines known to act as open channel blockers by entering the channel inner pore and reaching all the way up to the channel internal cavity (18).

In addition to the experiments with the chemically phosphorylated ShB peptide, we demonstrate here that this ball domain, both in solution as a free peptide or when forming part of the whole Shaker B K ${ }^{+}$channel, can be a substrate for enzymatic phosphorylation by Src, a tyrosine kinase abundant in neurons. Also, the phosphorylated peptide can be dephosphorylated in vitro by the PTB-1B phosphatase. This suggests that phosphorylation of $\mathrm{Y} 8$ in the ball domain could also occur in vivo to interconvert rapidly inactivating channels into delayed rectifiers and vice versa through a phosphorylation-dephosphorylation cycle. In such a hypothetical case, tyrosine phosphorylation on the ShB peptide would be equivalent to the reported serine phosphorylation on the inactivation peptide of the rapidly inactivating $\mathrm{K}_{\mathrm{v}} 3.4$ channel $(22,24)$, and thus, it could have important consequences on the regulation of neuronal excitability. Moreover, similarly to the observations reported here regarding the resemblance between the effects of tyrosine phosphorylation and the L7E mutation in the ShB peptide, mutation of serine residues to aspartates in the $\mathrm{K}_{\mathrm{v}} 3.4$ channel was found to mimic the action of protein kinase $\mathrm{C}$ (23). In any case, there is increasing evidence to support the fact that certain potassium channels exist in vivo as a complex with the kinases and phosphatases that regulate them (48-50), and therefore, covalent modification of these channels by phosphorylation at different sites, including the ball domains, appears as a likely candidate to further increase the already diverse functional patterns exhibited by the complex $\mathrm{K}^{+}$ channel superfamily.

\section{ACKNOWLEDGMENT}

We gratefully acknowledge the generous gift of antiShaker $\alpha$-ShHX1 polyclonal antibodies to our colleague Dr. Francisco Tejedor from the Instituto de Neurociencias (CSIC$\mathrm{UMH}$ ).

\section{REFERENCES}

1. Armstrong, C. M., and Bezanilla, F. (1977) J. Gen. Physiol. 70, 567-590.

2. Antz, C., and Fakler, B. (1998) News Physiol. Sci. 13, 177-182.

3. Hoshi, T., Zagotta, W. N., and Aldrich, R. W. (1990) Science 250, 533-538

4. MacKinnon, R., Aldrich, R. W., and Lee, A. W. (1993) Science 262, 757-559.

5. Gomez-Lagunas, F., and Armstrong, C. M. (1995) Biophys. J. 68, 89-95.

6. Zagotta, W. N., Hoshi, T., and Aldrich, R. W. (1990) Science 250, $568-571$.

7. Isacoff, E. Y., Jan, Y. N., and Jan, L. Y. (1991) Nature 353, 8690.

8. Dubinsky, W. P., Mayorka-Wark, O., and Schultz, S. (1992) Proc. Natl. Acad. Sci. U.S.A. 89, 1770-1774.

9. Toro, L., Stefani, E., and LaTorre, R. (1992) Neuron 9, 237245.

10. Foster, C. D., Chung, S., Zagotta, W. N., Aldrich, R. W., and Levitan, I. B. (1992) Neuron 9, 229-236.

11. Riquelme, G., Fernández, A. M., Encinar, J. A., Gonzalez-Ros, J. M., and Sepúlveda, F. V. (1999) Pfluegers Arch. 438, 879-882.

12. Kramer, R. H., Goulding, E., and Siegelbaum, S. A. (1994) Neuron $12,655-662$.

13. Murrell-Lagnado, R. D., and Aldrich, R. W. (1993) J. Gen. Physiol. 102, 949-975.

14. Jan, L. Y., and Jan, Y. N. (1992) Annu. Rev. Physiol. 54, 537555 .

15. Catterall, W. A. (1995) Annu. Rev. Biochem. 64, 493-531.

16. Kukuljan, M., Labarca, P., and LaTorre, R. (1995) Am. J. Physiol. Cell Physiol. 268, C535-C556.

17. Doyle, D. A., Morais-Cabral, J., Pfuetzner, R. A., Kuo, A., Gulbis, J. M., Cohen, S. L., Chait, B. T., and MacKinnon, R. (1998) Science 280, 69-77.

18. Zhou, M., Morais-Cabral, J. H., Mann, S., and MacKinnon, R. (2001) Nature 411, 657-661.

19. Fernández-Ballester, G., Gavilanes, F., Albar, J. P., Criado, C. Ferragut, J. A., and González-Ros, J. M. (1995) Biophys. J. 68, 858-865.

20. Encinar, J. A., Fernández, A. M., Gavilanes, F., Albar, J. P., Ferragut, J. A., and González-Ros, J. M. (1996) Biophys. J. 71, 1313-1323.

21. Encinar, J. A., Fernández, A. M., Gil-Martín, E., Gavilanes, F., Albar, J. P., Ferragut, J. A., and Gonzalez-Ros, J. M. (1998) Biochem. J. 331, 497-504.

22. Covarrubias, M., Wei, A., Salkoff, L., and Vyas, T. B. (1994) Neuron 13, 1403-1412.

23. Beck, E. J., Sorensen, R. G., Slater, S. J., and Covarrubias, M. (1998) J. Gen. Physiol. 112, 71-84.

24. Antz, C., Bauer, T., Kalbacher, H., Frank, R., Covarrubias, M., Kalbitzer, H. R., Ruppersberg, J. P., Baukrowitz, T., and Fakler, B. (1999) Nat. Struct. Biol. 6, 146-150.

25. Abbott, G. W., Mercer, E. A., Miller, R. T., Ramesh, B., and Srai, S. K. (1998) Biochemistry 37, 1640-1645.

26. Surewicz, W. K., Mantsch, H. H., and Chapman, D. (1993) Biochemistry 32, 389-394. 
27. Zhang, Y.-P., Lewis, R. N. A. H., Hodges, R. S., and McElhaney, R. N. (1992) Biochemistry 31, 11572-11578.

28. Ferrer-Montiel, A. V., Canaves, J. M., DasGupta, B. R., Wilson, M. C., and Montal, M. (1996) J. Biol. Chem. 271, 18322-18325.

29. López-Barneo, J., Hoshi, T., Heinemann, S. H., and Aldrich, R. W. (1993) Recept. Channels 1, 61-71.

30. Green, S., Issemann, J., and Sher, E. (1988) Nucleic Acids Res. $16,369$.

31. Fernández, A. M., Molina, A., Encinar, J. A., Gavilanes, F., LópezBarneo, J., and González-Ros, J. M. (1996) FEBS Lett. 398, $81-$ 86.

32. Hamill, O. P., Marty, A., Neher, E., Sakmann, B., and Sigworth, F. J. (1981) Pfluegers Arch. 391, 85-100.

33. Ferrer-Montiel, A., and Montal, M. (1994) Methods Companion Methods Enzymol. 6, 60-69.

34. Caprini, M., Ferroni, F., Planell-Cases, R., Rueda, J., Rapisarda, C., Ferrer-Montiel, A., and Montal, M. (2001) J. Biol. Chem. 276, 21070-21076.

35. Ferrer-Montiel, A. V., Sun, W., and Montal, M. (1995) Proc. Natl. Acad. Sci. U.S.A. 92, 8021-8025.

36. Rogero, O., and Tejedor, F. J. (1995) J. Biol. Chem. 270, 2574625751.

37. Mendelsohn, R., and Mantsch, H. H. (1986) in Progress in Protein-Lipid Interactions (Watts, A., and DePont, A., Eds.) pp 103-146, Elsevier Science, B.V., Amsterdam.

38. Castresana, J., Fernández-Ballester, G., Fernández, A. M., Laynez, J. L., Arrondo, J. L. R., Ferragut, J. A., and González-Ros, J. M. (1992) FEBS Lett. 314, 171-175.

39. Villar, M. T., Artigues, A., Ferragut, J. A., and González-Ros, J.
M. (1988) Biochim. Biophys. Acta 938, 35-43

40. Rusanescu, G., Qi, H., Thomas, S. H., Brugge, J. S., and Halegoua, S. (1995) Neuron 15, 1415-1425.

41. Lev, S., Moreno, H., Martínez, R., Canoll, P., Peles, E., Musacchio, J. M., Plowman, G. D., Rudy, B., and Schlessinger, J. (1995) Nature 376, 737-745.

42. Stewart, A. A. (2000) in Protein phosphorylation: a practical approach (Hardie, G., Ed.) pp 145-171, IRL Press and Oxford University Press, Oxford.

43. Santacruz-Toloza, L., Huang, Y., John, S. A., and Papazian, D. M. (1994) Biochemistry 33, 5607-5613.

44. Kamb, A., Iverson, L. E., and Tanouye, M. A. (1987) Cell 50, 405-413.

45. Papahadjopoulos, D., Moscarello, M., Eylar, E. H., and Isac, T. (1975) Biochim. Biophys. Acta 401, 317-335.

46. Jan, L. Y., and Jan, Y. N. (1997) Annu. Rev. Neurosci. 20, 91123.

47. Hille, B. (1992) in Ionic Channels of Excitable Membranes, 2nd ed., 607 pp, Sinauer Associates, Sunderland, MA.

48. Jonas, E. A., and Kaczmarek, L. K. (1996) Curr. Opin. Neurobiol. 6, 318-323

49. Davis, M. J., Wu, X., Nurkiewicz, T. R., Kawasaki, J., Gui, P., Hill, M. A., and Wilson, E. (2001) Am. J. Physiol. Heart Circ. Physiol. 281, H1835-H1862.

50. Levitan, I. B. (1999) Adv. Second Messenger Phospho-protein Res. $33,3-22$.

BI020188U 